\title{
LINKAGE ORDINANCES AND TRADITIONAL EXACTIONS ANALYSIS: THE CONNECTION BETWEEN OFFICE DEVELOPMENT AND HOUSING
}

\author{
JEROLD S. KAYDEN* \\ and RoBert Pollard $†$
}

\section{INTRODUCTION}

Under the rubrics of due process, equal protection, and just compensation, courts have traditionally subjected mandatory subdivision development exactions to a "reasonable relationship" test connecting the exaction to public needs generated by new development." Although the tightness of the required nexus has varied over the years from one jurisdiction to another, ${ }^{2}$ the basic analytical approach has garnered universal judicial acceptance. ${ }^{3}$ Thus, under this framework, courts have validated various types

Copyright $@ 1987$ by Law and Contemporary Problems

* Gerald D. Hines Lecturer in Real Estate, Harvard Graduate School of Design; Of Counsel, Warner and Stackpole, Boston, Massachusetts.

$\dagger$ Fellow, Lincoln Institute of Land Policy, Cambridge, Massachusetts; Independent Consultant, State and Local Governments.

1. See, e.g., Jordan v. Village of Menomonee Falls, 28 Wis. 2d 608, 137 N.W.2d 442 (1965), appeal dismissed, 385 U.S. 4 (1966); see also Heyman \& Gilhool, The Constitutionality of Imposing Increased Community Costs on New Suburban Residents through Subdivision Exactions, 73 YALE L.J. 1119, 1122-30 (1964); Johnston, Constitutionality of Subdivision Control Exactions: The Quest for a Rationale, 52 CoRnELL L.Q. 871, 885-87 (1967).

2. Compare Pioneer Trust \& Sav. Bank v. Village of Mount Prospect, 22 Ill. 2d 375, 381-82, 176 N.E.2d 799, 802 (1961) (requiring that exaction demanded from development be "specifically and uniquely attributable" to it) with Associated Home Builders v. City of Walnut Creek, 4 Cal. 3d 633, 638, 484 P.2d 606, 610, 94 Cal. Rptr. 630, 634, appeal dismissed, 404 U.S. 878 (1971) (requiring only that there be a "general public need" for exacted amenity arising from present and future developments).

3. Under the standard adumbrated by the United States Supreme Court for reviewing due process and equal protection challenges to socioeconomic legislation, the inquiry is whether the legislature has chosen reasonable methods to achieve legitimate ends. See, e.g., Hawaii Hous. Auth. v. Midkiff, 467 U.S. 229, $241-43$ (1984); Williamson v. Lee Optical, Inc., 348 U.S. 483, 487-88, 491 (1955); Zahn v. Board of Public Works, 274 U.S. 325, 328 (1927). In the case of exactions, "reasonable" means whether it is fair to ask this developer to pay for that end. Fairness demands that those bodies imposing an exaction show that the developer asked to address a need has created that need.

Some commentators suggest that the test applied to subdivision exactions is, or should be, more demanding than that applied to other forms of socioeconomic legislation. See, e.g., Bosselman \& Stroud, Mandatory Tithes: The Legality of Land Development Linkage, 9 NovA L.J. 381, 397 (1985); 
of exactions and fees: dedications of land for streets and parks, ${ }^{4}$ cash payments in lieu of such dedications, ${ }^{5}$ and fees for additional sewer and water, school, and other municipal facilities necessitated by new development. ${ }^{6}$

More recently, prompted partly by dwindling federal grants and increasing social concerns, some cities have expanded application of exactions to other classes of development and amenities. One new application, linkage, requires developers of office buildings to build housing or pay money to a city housing fund. ${ }^{7}$ The term "linkage," however, is not unambiguously self-defining in a substantive sense. ${ }^{8}$ Of course, by its very operation, such a technique forges a link between office development and housing, but this connection begs the important question whether there is an independent underlying link. The rationale for imposing an obligation on office developments is that, by attracting new residents to the city, office developments increase the need for housing. To the extent the additional need is not met by a commensurate

Richards \& Merriam, Land Dedications, In Lieu of Fees and Impact Fees: When are They Legal, in IMPACT Fees: A Developer's Manual at D5 (1984).

In reviewing exactions, courts have used a variety of phrases to describe the required test, including "reasonable relationship," Call v. City of W. Jordan, 606 P.2d 217, 220 (Utah 1979); "rational nexus," Land/Vest Properties, Inc. v. Town of Plainfield, 117 N.H. 817, 823, 379 A.2d 200, 204 (1977); "reasonably attributable," Home Builders Ass'n v. City of Kansas City, 555 S.W.2d 832, 835 (Mo. 1977); "reasonable connection," Jordan v. Village of Menomonee Falls, 28 Wis. 2d 608, 618, 137 N.W.2d 442, 448 (1965), appeal dismissed, 385 U.S. 4 (1966); and "rational basis," Billings Properties, Inc. v. Yellowstone County, 144 Mont. 25, 36, 394 P.2d 182, 188 (1964). As a matter of dictionary definition, it is difficult to see any differences between them. Only careful review of the application of the nominally utilized phrase to the facts of the case will disclose any differences between the terms. Words aside, it is the extent of the connection required that defines the contours of the test.

Because many state court opinions fail to state explicitly whether they are analyzing challenged exactions under federal or state constitutional law, it is difficult to know whether more demanding state court tests derive from interpretations of individual state constitutional provisions or a potential misunderstanding of Supreme Court precedents.

4. See, e.g., Ayres v. City Council, 34 Cal. 2d 31, 207 P.2d 1 (1949); Billings Properties, Inc. v. Yellowstone County, 144 Mont. 25, 394 P.2d 182 (1964).

5. See, e.g., Jenad, Inc. v. Village of Scarsdale, 18 N.Y.2d 78, 218 N.E.2d 673, 271 N.Y.S.2d 955 (1966); Jordan v. Village of Menomonee Falls, 28 Wis. 2d 608, 137 N.W.2d 442 (1965), appeal dismissed, 385 U.S. 4 (1966).

6. See, e.g., Trent Meredith, Inc. v. City of Oxnard, 114 Cal. App. 3d 317, 170 Cal. Rptr. 685 (1981); Contractors \& Builders Ass'n v. City of Dunedin, 329 So. 2d 314 (Fla. 1976) (upholding principle of water and sewer fees), reconsidered on appeal from unpublished remand, 358 So. $2 \mathrm{~d} 846$ (Fla. Dist. Ct. App. 1978) (upholding specific impact fee), cert. denied, 370 So. 2d 458, cert. denied, 444 U.S. 867 (1979). Although exactions and impact fees technically are different land use techniques, the courts' constitutional analyses of them tend to be similar. See Richards \& Merriam, supra note 3, at D4; $c f$. Delaney, Gordon \& Hess, The Needs-Nexus Analysis: A Unified Test for Validating Subdivision Exactions, User Impact Fees and Linkage, Law \& Contemp. Probs., Winter 1987, at 139, 143-44.

7. Although many cities have discussed adopting such programs (for example, New York, Chicago, and Hartford), San Francisco and Boston are the only two large cities to have enacted formal ordinances. See Boston, Mass., Zoning Code art. 26 (1983), amended by Boston, Mass., Zoning Code art. 26A (1986); San Francisco, Cal., Ordinance 358-85 (Aug. 18, 1985).

8. It is unclear how this technique came to be known popularly as linkage. San Francisco, the first city to adopt a linkage program, initially called it the "Office/Housing Production Program," and subsequently the "Office Affordable Housing Production Program." See Keating, Linking Downtown Development to Broader Community Goals, 52 J. AM. PLAN. A. 133, 135 (1986). Boston changed the formal name from "Development Impact Project Exactions," Boston, Mass., Zoning Code art. 26 (1983), to "Development Impact Project Contribution," Boston, Mass., Zoning Code art. 26A (1986). 
increase in the housing supply, the greater housing scarcity will place upward pressure on housing prices. Therefore, it is fair to impose an obligation related to the additional need generated.

Some commentators and, privately, even some city officials, have characterized the justification of linkage based on the relationship between office development and housing need as nothing more than paying lip service to a prerequisite legal condition. ${ }^{9}$ Indeed, the argument continues, linkage is no more than a cynically veiled effort to tax one segment of society for redistribution to another while the "getting is good." Accordingly, the argument concludes, it is hardly surprising that cities such as San Francisco and Boston have enacted linkage programs. ${ }^{10}$ After all, their respective development booms and political environments allow the imposition of such extra burdens. ${ }^{11}$

The unanswered question surprisingly receiving short shrift is whether linkage in fact can be justified under the traditional reasonable relationship test, or whether an alternative justification is necessary. This article analyzes whether linkage does satisfy the traditional test. For purposes of this article, the "reasonable relationship" test describes the patchwork of analyses employed by many jurisdictions. The test has two central components: ${ }^{12}$ (1) whether the development creates a need that it should be asked to address; and (2) whether the obligation imposed on the development is proportional to the need created. ${ }^{13}$

9. See Connors \& High, The Expanding Circle of Exactions: From Dedication to Linkage, LAw \& Contemp. Probs., Winter 1987, at 69.

10. See supra note 7.

11. In recommending establishment of a linkage program, a mayoral advisory group in Boston, composed of business and neighborhood leaders, public officials, and academics, relied in part on this justification:

Boston has an opportunity in the eighties that few other cities have-to make important strides in bringing its disadvantaged population into the mainstream of American life through jobs, development, and housing strategies. That opportunity is afforded more than any other factor by a strong and growing private economy-a relatively recent development in Boston. We would disserve those who labored for decades to build the foundations of prosperity if we either took that strong economy for granted or assumed its permanence. Those who seek to extend the benefits of that economy must also be its custodians-and it is in that spirit that the Advisory Group offers its linkage program.

Advisory Group, Linkage Between Downtown Development and Neighborhood Housing: Report to the Mayor 1 (1983); see also Porter, The Office/Housing Linkage Issue, Urb. Land, Sept. 1985 , at 16 .

San Francisco's building boom has recently abated, see N.Y. Times, Mar. 24, 1986, at D1, col. 2, but Boston continues to enjoy fairly robust growth, see Boston Globe, Oct. 21, 1986, at 1, col. 1 .

12. Some courts additionally require that the exacted dedication or funds be used at least in part for the benefit of the development. See, e.g., City of College Station v. Turtle Rock Corp., 680 S.W.2d 802, 807 (Tex. 1984); Call v. City of W. Jordan, 606 P.2d 217, 220 (Utah 1979). This extra element provides the reviewing court with further-though hardly conclusive-evidence that the exaction is related to the needs created by the development.

13. In applying these two components, the question remains whether standard rules of judicial deference to the local legislative body should apply. For example, how much evidence must the local government adduce in the courtroom to show that a need has been created? Is it enough to argue it is conceivable that the need exists? Exaction opinions never claim to use heightened scrutiny standards, and some even explicitly adopt the language of minimal scrutiny appropriate in the review of socioeconomic legislation. See, e.g., Oregon State Homebuilders Ass'n v. City of Tigard, $43 \mathrm{Or}$. 
Specifically, this article investigates the link between office development and housing in the city of Boston. ${ }^{14}$ It finds, first, that Boston office development is responsible for attracting new-resident employees who need housing. Second, it finds that the linkage obligation imposed on office development is proportionate to the need created. The article concludes, therefore, that there is a sufficient connection between office development and housing in Boston to justify linkage under the reasonable relationship test. $^{15}$

\section{II}

\section{The Boston Linkage Ordinance}

Article 26A of the Boston Zoning Code requires any office developer proposing to build in excess of 100,000 square feet, ${ }^{16}$ and seeking a variance, conditional use permit, exception, zoning map change, or text amendment, ${ }^{17}$

App. 791, 797-98, 604 P.2d 886, 890 (1979). Nevertheless, it is clear from the outcome of some cases that some courts apply a heightened standard of review. Without deciding the correctness of either standard, this article explores actual evidence underpinning a connection between office development and housing.

14. This analysis is drawn in part from a 1986 study conducted by the authors under contract with the Boston Redevelopment Authority. J. Kayden, K. Case \& R. Pollard, The Linkage Between Office Development and Housing Costs In the City of Boston (Jan. 1986) [hereinafter Boston Linkage Study] (unpublished study). See infra notes 24-28 and accompanying text.

15. This article's discussion of linkage focuses specifically on the impact of office development on housing. The narrow focus does not suggest, however, that policy analysts should miss the forest for the trees by ignoring the question whether, on balance, office development is a positive or negative phenomenon for the city and its constituent groups. Of course, benefits and costs of office development accrue differently to various sectors of the public. For city government, increased tax revenues are a major benefit while increased municipal services are a major cost. For residents, additional employment opportunities constitute an important benefit while increased housing prices and greater traffic congestion are major costs. In analyzing such benefits and costs, it is useful to disaggregate them according to their incidence upon specific groups. See J. Kayden, Incentive Zoning in New York City: A Cost-Benefit Analysis 17 (1978). Nevertheless, if the overall impact of linkage is to discourage business development in the city, with a concomitant loss in employment base and tax revenue, then linkage may, in effect, "kill the goose that lays the golden eggs."

16. In addition to new construction, article 26A applies to enlargement or substantial rehabilitation of more than 100,000 square feet in existing buildings. Boston, Mass., Zoning Code art. 26A, \& 2(1) (1986).

17. As drafted, Boston's linkage obligation is optional, not mandatory. Only those developers seeking some form of discretionary action from the city-"a variance, conditional use permit, exception or zoning map or text amendment"- are subject to its requirements. Boston, MAss., Zoning CoDE art. 26A, $\$ 3$ (1986). It follows that those developers wishing to develop as a matter of right are not subject to the ordinance. In this way, Boston's linkage program can be viewed as an exercise of incentive zoning. See 2 A. Rathropf \& D. Rathkopf, The Law of Zoning and Planning $\S 17.06(2)$, at 53 (4th ed. 1986) ("incentive zoning may be defined as the relaxation of certain restrictions in a zoning ordinance in return for the provision by a developer of a specified amount of lower income housing units").

Developers would insist that the reality of real estate development in Boston renders this interpretation of the ordinance little more than hypertechnical statutory reading. They would assert that it is impossible to build any large development in the city as of right, and would point to Boston's outdated zoning code and economically unrealistic maximum density limitations to support their views. Thus, they would conclude, any notion of voluntariness associated with the linkage obligation is purely chimerical.

Resolution of this debate turns primarily on an empirical proposition. If matter-of-right development in Boston is more than a theoretical possibility, then characterizing article 26A as a form of incentive zoning may be appropriate. If not, then such a view would be unconvincing. 
to contribute to a housing trust fund or to build low- and moderate-income housing. The payment option, known as the "housing contribution grant," is five dollars for each square foot of office space over 100,000 square feet, payable over a seven-year period in equal annual installments. ${ }^{18}$ The build option, known as the "housing creation option," requires development of low- and moderate-income housing at a cost at least equal to the housing contribution grant. Under the linkage ordinance, the city has obtained over $\$ 35$ million in commitments from private office developers but has yet to expend funds for any specific project. ${ }^{19}$

\section{III}

\section{Who Is Responsible and Who Actually Pays?}

A preliminary question is whether it is logical to hold office development responsible for attracting new-resident employees to the city. After all, office developers do not create the jobs held by employees of office building tenants; they merely develop buildings that accommodate employees. Thus, it is arguable that, if anyone is responsible for attracting new-resident employees to the city, it is the firms that employ them. To carry this argument even a step further, perhaps ultimate responsibility rests with the buyers of goods and services produced by these firms. ${ }^{20}$

Even attributing responsibility to consumers, however, does not by itself render it improper to place the linkage obligation on developers. The reason is that the party from whom an exaction is obtained is not necessarily the same party who ultimately bears the financial burden of the exaction. ${ }^{21}$ It is possible that developers themselves may ultimately pay the fee in the form of lower profits, or landowners may pay in the form of reduced property values. It is also possible, however, that the linkage obligation will be passed on to office tenants through higher rents or, ultimately, to consumers through

18. The first installment is due upon issuance of a building permit; the remaining six are due on the yearly anniversaries of the first payment. Boston, Mass., Zoning Code art. 26A, § 2(3)(a) (1986). Under the originally enacted 1983 linkage provision, developers were required to pay five dollars per square foot over a 12-year period. Id. art. $26, \S \S 2(3)(\mathrm{a}), 3(2)(\mathrm{a})(1983)$.

19. Boston Redev. Auth., Linkage Proposal Fact Sheet (1986) [hereinafter Linkage Fact SHEET]

20. Of course, it is also true that, but for the companies that actually construct the buildings, firms that want space would have to locate elsewhere. And without landowners or lenders, there would be no development sites or sources of financing. This sort of finger pointing may open a Pandora's box. Are housing subdivision developers responsible for increased school attendance, roadway congestion, or sewer usage? Are not the residents themselves causing these increased demands on services necessitating the exaction? What about employers of the new residents who strongly influenced their residential location decision? Despite these conceptual problems, courts reviewing subdivision exactions have no trouble with the general practice of collecting these exactions from the developer. Without adopting David Hume's ultimate skepticism about necessary causation, which would lead to abandonment of the inquiry altogether, there is a quality of endless regression here which suggests an application of Ockham's razor.

21. The ultimate allocation of the burden may be referred to as the true "incidence" of the linkage obligation. Cf. R. Musgrave \& P. Musgrave, Public Finance in Theory and Practice $427-$ 41 (3d ed. 1980); Ellickson, The Irony of "Inclusionary" Zoning, 54 S. CAL. L. Rev. 1167, 1187-91 (1981). 
higher prices. Under the latter scenario, the developer is little more than a convenient fee collector. ${ }^{22}$

Resolution of this debate, even if possible, ${ }^{23}$ should be unnecessary if a court applies the reasonable relationship test to linkage obligations. It should be enough that there are reasonable arguments that support allocating responsibility to the developer, or, in the alternative, evidence showing that the linkage obligation is passed on to the responsible party.

\section{IV}

\section{Does Office Development Create a Need for Housing?}

\section{A. Counting New-Resident Employees}

To determine whether office development in fact creates a need for housing, the authors conducted a survey to determine what proportion of current office employees moved to Boston because of jobs taken in Boston office buildings. ${ }^{24}$ A person's residential location decision often depends on a variety of interdependent factors, including availability and cost of housing and transportation, quality of neighborhoods, and lifestyle choices. Workplace location, however, is an especially significant factor. Because traveling to work is costly in terms of both time and money, other things being equal, people prefer to live close to their workplace ${ }^{25}$ Thus, persons obtaining jobs in Boston's office buildings may decide to live in the city.

Of the 1,237 office employees responding to the survey, 268, or $22 \%$, stated that they were residents of Boston. Of these 268 resident employees, 85 , or about $7 \%$, of all office employees ${ }^{26}$ answered that a major reason for their move to Boston was a job taken in an office building. ${ }^{27}$

Combining these survey results with past trends in Boston office employment growth, it is possible to estimate residential migration induced

22. There are transaction costs associated with the collection of linkage obligations. It probably costs less to collect the obligation from developers than from any other group that may be responsible.

23. The "who actually pays" determination is elusive because the extent to which developers can shift the linkage obligation to others hinges on a variety of complex economic factors. For example, the willingness of tenants to pay higher rents reflecting the linkage obligation depends on, inter alia, how attractive they find substitutes for Boston office locations.

24. Employees working in eleven of the fourteen major private office buildings constructed since 1975 were surveyed. See Boston Linkage Study, supra note 14, at 16-17. Prepaid mail-in survey forms were distributed over a period of two days to individuals as they entered the office buildings between the hours of 7:30 a.m. and 9:15 a.m. A pretest survey was conducted at one of the buildings prior to administration of the full survey.

This analysis only uses data obtained from office buildings located downtown. It was reasonable to focus on downtown development because the linkage obligation attaches only to developments of more than 100,000 square feet and such developments are almost always built within the downtown district.

25. This preference is well documented in urban economics literature. E.g., E. Mill.s, Urban Economics 60-65 (1972).

26. This survey result is statistically significant at a .05 level.

27. The survey consisted of a series of questions. See Boston Linkage Study, supra note 14, at 1819. The survey directed two questions to Boston residents. They were first asked, "Did you live in Boston before you took a job in a downtown Boston office building?" If the answer was "no," 
by office development. Table 1 shows that, for the 8 years from 1976 to 1984,28 office employment in Boston increased by 29,000 workers. The survey results suggest that $7 \%$, or 2,030 , of these workers moved to the city because of their jobs. Office space growth of 6.3 million square feet for the same 8-year period accommodated the 2,030 new-resident employees. Dividing this office space growth by the new-resident employees reveals that 1 new-resident employee arrives for every 3,103 square feet of office space added. Alternatively stated, every 1,000 square feet of additional office space attracts .31 new-resident employees.

\section{TABLE 1}

\section{Private Office Space, Private Office Employment, 1976-1995}

$\begin{array}{ll}\text { YEAR } & \text { SPACE }^{\mathrm{a}} \\ 1976 & 35,900,000 \text { square feet } \\ 1980 & 37,000,000 \text { square feet } \\ 1984 & 42,200,000 \text { square feet } \\ 1990 & 50,100,000 \text { square feet } \\ & \text { (projected) } \\ 1995 & 57,100,000 \text { square feet } \\ & \text { (projected) }\end{array}$

\section{PRIVATE OFFICE EMPLOYMENT $^{\text {b }}$}

124,000 persons 140,000 persons 153,000 persons not available

not available

a'Source: Boston Redev. Auth., Boston's Recent Performance and Prospects for the Future: The Outlook for Demand and Supply of Office Space, Hotel Rooms and Housing at table 13 (1985).

'Source: Boston Redev. Auth., Boston Employment, City-wide, Downtown, Downtown Office, and Remainder of Boston: 1976-1984 and Projections to 1990 and 1995 at table 3 (1985).

Office development has actually accounted for more residential migration than the survey results indicate. First, office development has a multiplier effect on non-office employment. Some people who work in non-office atmospheres (janitors, messengers, restaurant workers) created to support the expanded level of office activity also move to the city. Second, some individuals who moved to Boston for a job in an office building no longer work in one. These two elements make the survey's estimate of residential migration due to office development a conservative one.

residents were then asked, "Was a job you took in a downtown Boston office building a major reason that you moved to Boston?"

There are frequently several important and interrelated reasons for making a move. For example, a new-resident employee presumably would not move to Boston if he or she did not like the city. Thus, for that person, both the job and personal preference might be decisive to the move. By asking whether the job was a major reason for the move, the survey attempted to reflect the reality of multifactored decision making. Forcing persons to choose a single decisive factor might distort survey results, especially for those questions in which residents were asked to identify, in retrospect, their reasons for a particular action. For purposes of this study, persons stating that their Boston office job was a major reason for their move to Boston are counted as new-resident employees attributable to office development.

28. Using data from a period of years instead of a single year mitigates the possibility of choosing an unrepresentative year. This 8 -year period was selected on the basis of data availability. In some cases, however, study data is available only for a 1-year period, in which case average- and single-year data are used. 


\section{B. Measuring the Impact of New-Resident Employees on the Housing Market}

The survey results show that office development increases the need for housing in Boston. Just as new subdivisions render park land more scarce by increasing the number of resident users in the community, office development makes housing more scarce by attracting new-resident employees. ${ }^{29}$ Unlike parks, streets, schools, and other municipal facilities provided primarily by the public sector, however, most housing is provided by the private sector. Whereas increased demand for park land results either in overcrowding or expenditure of public funds to pay for park land acquisition, increased demand for housing sets in motion a different chain of events.

If the private sector responds to office development by immediately supplying sufficient additional housing at unchanged prices, then the increased need would be fully met and the rationale for linkage undercut. Housing development economics, however, suggests that this result is unlikely. By using part of the fixed quantity of land in the city, office development decreases land available for residential purposes, thereby increasing land prices. As a significant component of residential development costs, higher land prices will tend to offset additional income potentially derived from the higher housing prices resulting from the additional demand of new-resident employees.

In subdivision exaction cases, courts routinely assume that the community will experience harm if the need for the exacted amenity remains unmet. For example, they assume new subdivisions will harm existing park users by increasing park congestion. ${ }^{30}$ This same reasoning applies to office development and its housing impact. Higher housing prices resulting from the additional demand of new-resident employees necessarily mean that existing residents will be harmed by spending more for the same amount of housing. Thus, in both cases, it is reasonable to force the subdivision or office

29. Higher housing costs and overcrowded park lands represent third party or spillover effects from new development, which economists refer to as externalities. Economists distinguish between two types of externalities, however: real or technological ones that are not transmitted through the price system, and pecuniary ones that are so transmitted. See S. Rhoads, The Economist's View of THE WORLD 269 (1985). Although third parties are injured in both cases, resources are misallocated, and economic inefficiency is thereby created, only in the case of real externalities.

When new subdivision residents use neighborhood parks, thereby reducing the available supply of parks, the market will not respond through higher prices to restrict park use or increase the supply of park land. Put another way, the private cost to the new subdivision-resident user is less than the true cost to society, resulting in deadweight or efficiency loss. In contrast, higher prices in the housing market caused by new-resident employees translate into higher revenues received by property owners. The higher prices are not due to inefficiencies, but rather to the fact that more people want to live in the limited housing available. This distinction is also sometimes described as the difference between collective goods (parks, streets) and private goods (housing).

If an economic efficiency argument for office-housing linkage is unavailing, it is still possible to make an equity argument. It may be equitable to compensate those third parties experiencing housing cost increases, that is, pecuniary externalities, because of office development.

30. E.g., Associated Home Builders v. City of Walnut Creek, 4 Cal. 3d 633, 639, 484 P.2d 606, 611,94 Cal. Rptr. 630, 635 (noting that as a result of increasing population, "local officials have been besieged by demands for more park space"), appeal dismissed, 404 U.S. 878 (1971). 
development to bear the burden of avoiding adverse effects on other members of the community.

In contrast to subdivision exaction amenities, where harm may be difficult to quantify, reliable measures of harm do exist for housing. By using the survey results with evidence from Boston and other housing markets, it is possible to find a reasonable approximation of the price impact new-resident employees will have in the housing market. ${ }^{31}$ The average residence in Boston contains 1.4 workers. $^{32}$ Thus, in-migration of 2,030 new-resident employees between 1976 and 1984 created a demand for 1,450 additional residences. Sixty-eight percent of all Boston housing units are rental units. ${ }^{33}$ Assuming that new-resident employees are as likely to live in such units as did that proportion of all Boston residents, then office development between 1976 and 1984 created a demand for 986 rental units, or 123 on an average annual basis.

Boston has approximately 151,000 private rental housing units. ${ }^{34}$ A $4 \%$ housing vacancy rate $^{35}$ translates into approximately 6,040 rental units available. Inserting an additional average annual demand of 123 units created by office development reduces the number of available rental units by $2 \% .{ }^{36}$ Assuming the price elasticity of demand is 1 , this $2 \%$ increase in the demand for available apartments causes all rents to increase by $2 \% .{ }^{37}$

31. The quantitative results presented in this article should be taken as indicative, rather than definitive, measurements of the impact of office development on housing prices. Given the complexity and dynamism of urban housing markets, it is difficult to isolate with precision individual factors affecting price. In addition, practical limitations necessitate reliance on general data from Boston's office and housing markets to make the specific calculations needed for this analysis. These data are found in Boston Redev. Auth., Boston Employment, Citywide, Downtown, Downtown Office, and Remainder of Boston 1976-1984 and Projections to 1990 and 1995 (1985), and Boston Redev. Auth., Boston's Recent Performance and Prospects for the Future: The Outlook for Demand and Supply of Office Space, Hotel Rooms and Housing (1985)

32. Informal Memorandum of the Boston Redevelopment Authority (Dec. 1985).

33. See 5 Boston Redev. Auth., Boston at Mid Decade: Results of the 1985 Household Survey: Characteristics of Housing Units at table 6 (1985) [hereinafter Boston at Mid DeCade]. Property owners will escape the burden of increased housing costs through appreciation in the value of their property. Renters, on the other hand, do not enjoy the benefits of capital appreciation and thus will bear the brunt of higher housing costs. For this reason, this article will limit itself to estimates of increased costs borne by renters.

34. In 1985, there were 249,000 housing units in the city. See Boston Redev. Auth., Boston's Housing Stock Changes, 1980 to 1985, at 2 (1985). Subtracting the 18,000 nonprivate rental units operated by the Boston Housing Authority, see id. at 2, from the $68 \%$, or 169,000 units that were rented, see supra text accompanying note 33 , leaves 151,000 units having rents that should adjust to market conditions.

35. See Boston at Mid Decade, supra note 33, table 2.

36. By calculating that the number of vacant units in 1984 has been reduced only by the number of new-resident employees attracted by office development for that year, this study implicitly assumes that the supply of housing has already adjusted to accommodate all new-resident employees attracted in previous years.

37. Price elasticity of demand measures the responsiveness of price to changes in demand. E.g., E. Mills, Urban Economics 164 (1972). Studies of urban housing markets suggest that a reasonable approximation of the price elasticity of demand for housing is 1 , meaning that a $1 \%$ increase (decrease) in the demand for housing leads to a $1 \%$ increase (decrease) in its price. Id. Rents, like other prices, are determined at the margin. See P. Heyne, The Economic Way of Thinking 53 (1980). Current tenants will face higher rents when expiration of their leases permits landlords to increase rents. 
Using an average rent of $\$ 425$ per month, ${ }^{38}$ the entrance into the Boston housing market of new-resident employees results in rent increases of $\$ 8.50$ per month, or $\$ 102$ per year, for the average rental unit. Given 151,000 units with prices that adjust to market conditions, annual rents in Boston are $\$ 15.4$ million higher than they would be in the absence of new-resident employees working in office buildings. ${ }^{39}$

The impact on housing prices may also be expressed as a function of office square feet. From 1976 to 1984 , Boston's office space inventory grew by 6.3 million square feet, or an average of 790,000 square feet per year. ${ }^{40}$ Dividing an increased annual housing price of $\$ 15.4$ million by an average annual office growth of 790,000 square feet indicates that each square foot of office space results in annual rental housing price increases of $\$ 19.50$.

\section{Is the Financial Burden of Linkage Proportionate to the Housing Need Created?}

The second component of the reasonable relationship test asks whether the linkage obligation imposed on office development is proportionate to the housing need created. In the case of subdivision exactions for park land, courts traditionally examine whether the amount of land required for dedication or cash-in-lieu payments is proportional to the need for that land created by the subdivision. Thus, for example, if the subdivision creates a need for one additional acre of park land, it is reasonable for that subdivision to provide or pay for that one acre. When a community requires that a subdivision provide such land or its cash equivalent, it is guaranteeing that the community not be harmed by park overcrowding caused by the new subdivision. The exacted land offsets the increased scarcity created by new subdivision-resident park users.

In the case of linkage, the community likewise wants to ensure that it does not incur harm through increased housing scarcity caused by office development. Unlike parks, however, a market for housing exists and housing prices reflect relative scarcity. Therefore, it is reasonable to compare the financial burden of linkage imposed on office developments to changes in housing prices. If the linkage obligation is proportionate to the housing price impact, then needs can be said to have been addressed and the second part of the reasonable relationship test met.

This article's analysis estimates that office development generates housing price impacts of $\$ 19.50$ for each square foot of office space. Boston's current linkage obligation is $\$ 5$ per square foot payable over 7 years, which represents a present value burden of $\$ 3.83 .41$ Consequently, the housing price impact

38. Boston at Mid Decade, supra note 33, at 11 .

39. The impact of rental prices reveals that, whatever the overall wisdom of policies designed to revitalize downtowns and attract the middle class back to the cities, there are costs as well as benefits.

40. See Table 1, supra p. 133.

41. The present value was calculated using a discount rate of $10 \%$. See Boston Redev. Auth., Questions and Answers on the Linkage Program 1 (1986). The initial linkage obligation enacted in 1983 was $\$ 5$ per square foot over 12 years, representing a present value burden of $\$ 2.58$. Id. 
measuring housing need is substantially greater than the linkage obligation imposed on developments. ${ }^{42}$

\section{ConClusion}

Some assert that, by granting office developers the privilege of making profitable use of land, the state has already provided enough reason to support the constitutionality of linkage. ${ }^{43}$ Such an argument, however, is merely "icing on the cake." Linkage ordinances that attempt to match observable housing need and corresponding price impacts fairly with obligations imposed on office development should be able to pass muster under the traditional reasonable relationship test used by courts to analyze development exactions. ${ }^{44}$

42. No linkage funds have yet been expended. Indeed, actual receipt of the first linkage payment is not expected until April, 1987. See Linkage Fact SheEt, supra note 19. Therefore, it is too early to judge whether and how linkage will be used to address the housing need created.

The Boston linkage ordinance states that the housing creation option can be met only "by creating or causing to be created housing units, for occupancy exclusively by low and moderate income residents of the City." Boston, Mass., Zoning Code art. 26A, § 2(3)(A) (1986). The language of the ordinance is ambiguous, however, as to whether housing contribution grants collected by the city must likewise be spent for low- and moderate-income housing. The only explicit restriction on use of grant money is the requirement that $10 \%$ be spent on housing in neighborhoods immediately adjacent to the office development paying the linkage amount. See id. $\S 2(3)(\mathrm{C})$.

In its statement of purpose, the ordinance is no more specific:

The purpose of this article is to promote the public health, safety, convenience and welfare; to prevent overcrowding and deterioration of existing housing; to preserve and increase the City's housing stock; to establish a balance between new, large-scale real estate development and the housing needs of the City; and to mitigate the impacts of large-scale development on the available supply of low and moderate income housing, by provisions designed to:

1. Afford review and regulation of large-scale real estate development projects which directly and indirectly displace low or moderate income residents from housing units or contribute to an increase in the costs of housing.

2. Increase the availability of low and moderate income housing. . . . Id. art. $26 \mathrm{~A}, \S 1$.

Because low- and moderate-income persons are more likely than high-income persons to be renters, it would be reasonable for the city to direct linkage funds primarily to such households. In any event, all renters, including some of the new-resident employees, stand to benefit from the addition to housing supply created by linkage obligations. Cf. Call v. City of W. Jordan, 614 P.2d 1257,1259 (Utah 1980) (rehearing) (exaction of park land or in-lieu payment need not be used solely to benefit the new subdivision).

43. See Boston Globe, Apr. 8, 1986, at 18, col. 1 (editorial); $c$. Trent Meredith, Inc. v. City of Oxnard, 114 Cal. App. 3d 317, 328, 170 Cal. Rptr. 685, 691 (1981) (fees); Jordan v. Village of Menomonee Falls, 28 Wis. 2d 608, 137 N.W.2d 442 (1965) (in-lieu cash payments), appeal dismissed, 385 U.S. 4 (1966). In Jordan, the court stated:

The municipality by approval of a proposed subdivision plat enables the subdivider to profit financially by selling the subdivision lots as home building sites and thus realizing a greater price than could have been obtained if he had sold his property as unplatted lands. In return for this benefit the municipality may require him to dedicate part of his platted land to meet a demand to which the municipality would not have been put but for the influx of people into the community to occupy the subdivision lots.

Id. at $619-20,137$ N.W. $2 \mathrm{~d}$ at 448 .

44. Although the methodology of this study is applicable to any jurisdiction that is contemplating a linkage program, the results of this study are specific to Boston. 
